\title{
Gender Equity and Power of Woman in India
}

\author{
Sharayu Potnis \\ Jain Degree College, Belgaum, India
}

\begin{abstract}
The idea of 'gender equity' in India is since Vedic age. Both man and woman are considered as an integral part of the society. The paper mentions how woman is powerful whether she belonged to Vedic age, medieval age or Modern age. She has proved her intellect and dignity in every age. Here her greatness lies because she never blamed men and patriarchal society alone for her agony and suppression. She has realized 'Life-force' that flows in her. India is one of the early countries in the world to give women the right to vote. India has more goddesses than any other religion. We find powerful women even in medieval age which is considered as 'the dark age' by European countries where women were like domesticated pets caged in the house. India has witnessed the 'energy' of woman in every part of country. We have dancers, poetesses, wives helping in administration of husbands, saints etc. Many women have revolted against social evils. Even in modern age, the problems like illiteracy, poverty, ignorance and their rights have not much bothered Indian woman whenever she has to show her capacity. We witness examples of Dalit women and women belonging to higher caste working for their families at the time of crisis as well as helping each other's families. Most of the widows in India shoulder the responsibility of their children and in-laws. Indian Legislation has always helped women with important acts. Indian woman, with her unconquerable energy that is coupled with the awareness of her rights, can make her family, society and her nation most powerful than ever. No doubt India would emerge as the gigantic nation in few years against all the odds.
\end{abstract}

Key words: gender equity, woman power, life-force, rights, Vedic age, medieval age, modern era.

\section{Introduction}

The gang rape of twenty three years old Indian girl at Delhi on 29 December, 2012 has trigged many archangels of debatable issues about the safety of woman's position in India. Thanks to the throng of millions those rushed on the streets to show concern for the ill-fated girl. The issue has led to many other women related topics like gender equity and the denial of womanpower in India. It is no surprise that the topic is vehemently discussed with no real solution rather frightening the development of the country. Astonishingly the land of five thousand years has never denied the essential intellectualism and dignity of Indian woman in any situation; rather woman has emerged as a decision-maker realizing her inner potentiality in every moment of her life. The paper mentions how Indian woman has appeared as an authoritative and strong woman whether she belonged to Vedic age, medieval age or modern age.

The word power is synonymous with the word Shakti and Shakti is the prevailing universal manifestation of the feminine qualities and she is goddess of strength and valour.The idea of 'gender equity' in India is perceived, constructed and rather consumed perfectly from ages. The idea has been viewed very differently from the western concept of gender equity that is because since Vedic age in India, man and woman both are considered as an integral part of family, society and nation. As the tradition says that they are two wheels of 'life chariot' and are considered as the symbols of knowledge and power.

Indian Women have occupied the essential part of Indian history from ages. In this land of contradictions, they play a greater role. It is said that they are the most oppressed in the world. It is also said at the same time that they are the one who are the most understanding, dignified, articulate and enjoy freedom to the extent. The question is, can these remarks be combined and taken up as strength? This is the question which is neither modern nor social in its origin. The roots are highly ancient and highly religious. Whenever there is a conflict, confusion and chaos, they have aroused, they have fought for their rights and never blamed men and patriarchal society alone for their agony and suppression. They have tried to find out the cause for their problems and have proved their wisdom and that finesse of woman. Here I am reminded of Bernard Shaw's theory "Life Force", the initial form of life which flows through the woman. Here lies the Gender Equity which is more meaningful than the word Equality. Equality emphasizes treating people the same. However, treating people the same doesn't accommodate significant differences which may affect the outcomes of equal treatment. Equity then would recognize difference and accommodate it in order to prevent the continuation of inequitable status quo. Equity emphasizes fairness in process and outcome and doesn't presume a hypothetical ideal and undifferentiated individual. Simple 'equality' as a concept doesn't recognize the very different conditions. 
Gender equity is a set of actions, attitudes and assumptions that provide opportunities and create expectations about individual.

The gender equity -right from the ancient through medieval to the modern times has always attracted debate. Some scholars opine that women enjoyed greater freedom in the days of yore; others hold that opposite is true. Some women enjoyed equal status with man in all fields. As I mentioned earlier, India is the land where woman emerged as the greatest gift of God. It is equally surprising to see that India is one of the early countries in the world to give women the right to vote. Whatever is the controversy that there was inequality or equality in Indian past, India has more goddesses than any other religion.

\section{The power of women in Vedic times:}

The status of women in early Hindu society is an enviable one. They could avail of the highest learning and there were many saints and philosophers among them. During Vedic times men and women had equal rights in all aspects of life including education and religion. Women enjoyed greater freedom in the Vedic period than in later period. It is said that she had more choice in choosing her life-companion. If she was left a widow there was no restrictions upon her re-marriage.

The Rig-Veda has referred to three women philosophers of ancient India, Lopamudra, Gargi and Maitreyi who have challenged their philosopher husbands in an open debate. They studied with men. The Vedic hymns inform us that both women and men were joint owners of family property. The daughter of a particular house, whether married or unmarried was able to get the right of inheritance in the property of her deceased father. They were actually involved and associated with men in every socio-religious ritual and ceremony. A wife was regarded as indispensable member of husband's family and a centre of domestic world. We have innumerable examples of brave independent minded scholarly women in ancient purans. In ancient India we hear the name of famous astronomer Arundhati.

"Among the many societies that can be found in the world, we have seen that some of the most venerating regard for women has been found in Vedic culture. The Vedic tradition has held a high regard for the qualities of women, and has retained the greatest respect within its tradition as seen in the honor it gives for the Goddess, who is portrayed as the feminine embodiment of important qualities and powers"(Stephen Knapp 1)

In Mahabharata epic women like Kunti, Draupadi have always proclaimed and demanded their authority and power. Kunti and her sons were deprived of their legal property in that male chauvinistic society. Kunti's unchallenging determination could get victory to her sons. One more important character Draupadi questioned the definition of Dharma when her honour was at stake in the game of dice. She protested against the inability of her husbands in giving protection to her. She insisted that her husbands should feel her insult. She willed to kill those who ridiculed her by pulling her Sari. Thus there was a war of righteousness. We read examples like Satyavati who raise some demands for Shantanu before getting married with him. There are instances like Gandhari and Madri who were married by taking bride-price. The system of Niyog allowed woman to take the responsibility as a mother and enjoy motherhood. In this system with the permission of her husband woman was allowed to conceive children with other man if her husband was unable to bear an heir to the throne. What wonders me is that despite law given by Manu which was prevalent in the society, women exhibited their perfect character. As a matter of fact, we can not come to the conclusion that Manu hated women and his code was primitive and barbaric because he was neither better nor worse than any other ancients who had this general attitude towards women. At the same time he has said that "Where women are respected, there the gods reside, the heavens open up and angels sing songs of praise"

\section{The power of woman in medieval times}

It is said that the medieval times which is known as 'dark age' in India and also in other countries, women were almost like domesticated pets caged in the house. Their position in the society was deteriorated during this period. However, the inscriptions, literary sources and sculptures of the period give us an astonishingly different picture of status of women in India. Many women became prominent in the fields of politics, literature, education and religion. Razia Sultan was the only woman monarch who ruled Delhi. The Gond queen Durgavati ruled for fifteen years before losing her life with Mughals. Chand Bibi defended Ahmednagar and Nur Jehan effectively exerted grand power. Shivaji's mother Jijabai was queen reagent because of her ability as a warrior. The Bhakti movement tried to restore woman's status and questioned certain forms of oppression. Mirabai-a female saint, Akka Mahadevi-poetesses were able to write poems in colloquial language to educate a common man. Karnataka has witnessed women who administered villages, towns, divisions and heralded social and religious institutions. Piriyaketaladevi, a queen of Chalukya Vikramaditya VI ruled three villages. According to the scripture of 1148 A.D. Lakkadevi was a village headman. Jakkiabbe ably administered seventy villages after premature death of her death. Mailalladevi, a senior queen of Someshwara-I 
ruled the important province of Banavasi comprising 12,000 villages. It is evident from an inscriptive of 1187 A.D. that the Jain nuns enjoyed the same amount of freedom as their male counterparts. There were female trustees, priestesses, philanthropists, musicians and scholars.

The historical sources of the period are abundantly filled with stories of accomplished women of the time. Shantaladevi, the Hoysala queen was an expert in singing, dancing and instrumental music. She also helped her illustrious husband Vishnuvardhana in administration. Many carvings in the temple depict that women had inclination in writing and reading. The social-reformers of that period like Basaweswar, Akkamahadevi have given immense value to women in the society. Basavanna's Mantra 'work is worship' allowed women to come out of their home and lead an active life in the fields, administrations and arts. Akkamahadevi has given worldly wisdom through her Vachanas. The folk songs were composed by ordinary women and one wonders at their syntax, semantics and rhymes. Eventhough woman in those days was unlettered, they could not be described as uncultured. The pages of history show us that every village had a religious leader who used to have discourse on religion, philosophy and culture which was attended by all women of the village. There are many instances where the widows shouldered the responsibilities of the family even though Sati was prevalent among certain classes. There was a class of men who trusted the intellectual capacity of women though not in physical ability. Achale was a lady of rare distinction and it is said that Chandramauli, a minister of the Hoysala Kings was the best husband for her. This is contrary to the normal belief of a wife being housewife looking after children and in-laws. These instances show that medieval men and women together made a complete and successful life. They were complimentary to each other and not competitive in all fields. Women faced hardships bravely. They exhibited their sense of social service. They were good housewives, pursued fine arts and when given a chance, proved as good administrators and fought and won the battles. In spiritual field also, they made their contributions.

\section{The power of woman in modern era}

At the same time when we view the status of women in other countries till the beginning of the 20 century, their plight is unbelievable. We are reminded of Hypatea, a brilliant and beautiful woman mathematician in Egypt was to put death because society could not tolerate intelligent woman. Women were denied the right to education till the middle of the 19 century in the west and it was not until 1928 that they were entitled to civil rights even in Britain. It is said that when Ibsen's Nora, the central character of his play 'Dolls house' left home by banging the door, the whole Europe shook.

We cannot completely highlight the glorious status of the woman in India but as and when there comes a situation they have proved the best. Their inspiring crusade is not ceased. Many known and unknown women have revolted against social evils and had a great concern about the plight of women. In one of the villages in Karnataka I have witnessed women belonging to high caste helping women of low caste during their pre-natal and post-natal periods. Such examples are witnessed every where in India. A group of Dalit women in Uthapuram in Tamilnadu led a funeral procession in the absence of their male relatives who were arrested following caste violence. Often woman power stalls muscle power. At the time of crisis religion and God have played secondary role and humanity ranks first. Great men like Mahatma Gandhi, Swami Vivekananda, and Mahatma Phule realized the power of women which they believed is a solid foundation for free India. It is true that there should be more change in attitude. The feeling of empathy rather than sympathy towards women surely gives promise that someday there could truly be complete equality for women in India and the world over.

It's perfect time for women to realize their significant role in nation building. Indian legal system is helping women to know about their rights and duties. They need to know their right to education, property and their status in her in-laws place. Indian legislation has stretched its helping arm towards woman from time to time. Here are some important acts.

1. The Hindu widow re-marriage act of 1856

2. The child marriage restraint act of 1929

3. The Hindi women's right to property act of 1937

4. The Hindu marriage act of 1955

5. The Hindu succession act of 1956

6. The suppression of immoral traffic in women and girls act of 1956-57

7. The dowry prohibition act of 1961

Recently a bill seeks to legalize commercial surrogacy has been drafted by the Indian Council of Medical Research which really upholds the supremacy of woman. It's the right hour for woman to fortify her position as a daughter, wife, daughter-in-law, mother and many more roles to play with the help of Indian legislation. Even at international level many actions have been taken to empower women especially The United 
Nations Development Programme which started at Rajasthan state in India. This has enabled women to be entrepreneurs which have given them a stable economic life and an understanding of working in team.

Today gender equity has proved greatly, but it is ongoing endeavor. Some skeptical eye-brows must have risen on how far and how long women's liberalism is effective but modern woman sees herself as a unique individual first and foremost. Few weird remarks by politicians and sages about the gang rape like- woman should not cross Lakshman-rekha by wearing western dresses or she could have called them 'brother'- need not worry her. Her family, friends, success and career fulfillment are by-products of knowing oneself. She continuously strives to improve her position in the society. She is decision maker. Today she is at par with men with regards to economic status. Despite the fact that external emancipation has boosted up her confidence, woman has to balance both her work and home place. She has to pour her instincts like love and patience at home especially her position as mother. She has to shape her children into good and efficient beings. However intelligent and professional she is, woman seeks security from her spouse both emotionally and financially. In one of the articles in Business World, Meera Seth analyses one of the situations where highly qualified woman colleague, who was the founder member and managing director of the company chooses to quit her work when she realizes that her children need her more than her money. Thus women proved to be evolved gender. They are capable of recognizing and balancing humanity with professionalism. Indian legislation has also helped woman from time to time to march towards liberty.

To sum up, the notion of gender equity is more in the mind of woman herself than the people around her. It's important for every woman to realize her abundant inner strength and energy which can get each one in the society on a right path. At the same time the society should allow her in all the fields including the field of decision-making. Even technology can help men and women to work equally. Today we face challenges like live-in relationship, gay marriages, increasing rape cases etc but India has capability to endure all phases of life. Out of this chaos, I am sure Indian woman again comes out brilliantly with all solutions. If some problems related to women are tackled at the grass-root level then surely India can visualize millennium development in a brighter and different sense. When the position of women declines then that society loses its equilibrium and harmony which ends up in disaster. Let us awake before that dooms 'day.

\section{References.}

[1]. Menon.L, "Women in India and abroad" in Women of India edited by T.A.Baig, Delhi, publications Division, 1958

[2]. Mitra, D.N. "A Hindu Wife", Ame.Jou.Soc. V.52, No 3, Nov 1946

[3]. Mody S.N. and Mhatre, S. "Slum women of Bombay" in Indian Women edited by D.Jain New Delhi, Publications division, 1975.

[4]. Narayan,V. "Women in India gifted with equal capacities and opportunities", Soc, wel, V 21 no7, Oct 1974.

[5]. Narula V. "Indian woman in changing society" Soc, Wel. V.14, No4, July 1967.

[6]. Nischal, K. "Rural women. Their rights, status and problems" Soc. Wel V 21, No11 Feb 1975

[7]. Knapp, Stephen. "Vedic Culture: the difference it can make in your life", 2006

\section{Secondary Sources}

1. India Today,

Frontline,

Business World,

Competition Success,

Google.com 